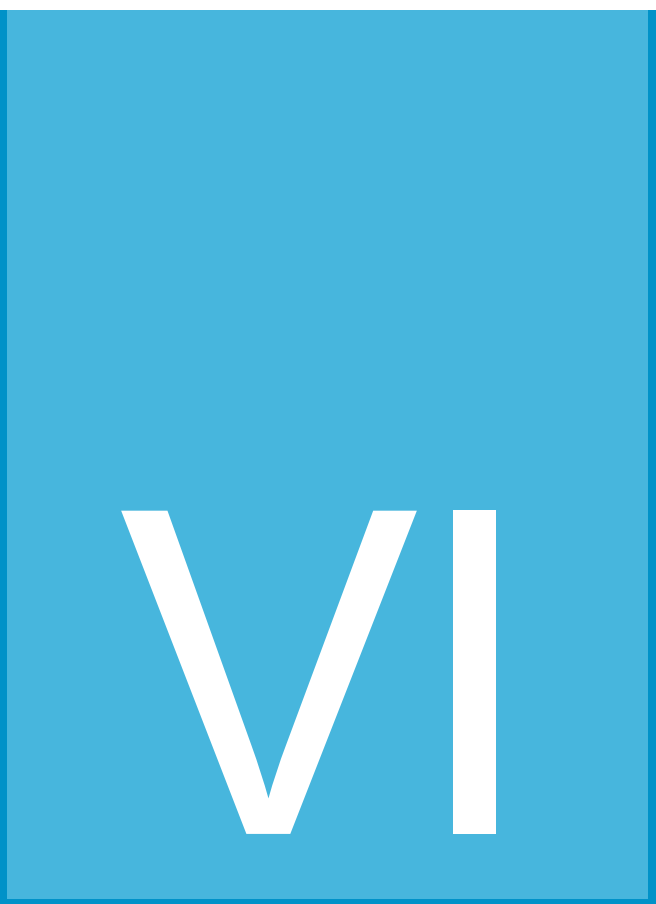

\title{
Ion’s Spiritual Journey
}

\section{Ion's Spiritual Journey}

Centro Universitário Adventista de São Paulo, Brazil

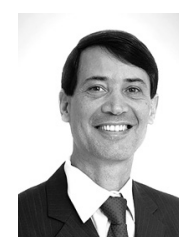

Milton L. Torres

Pós-doutor em literatura antiga pela Universidade Federal de Minas Gerais. Além disso, é doutor em língua grega pela Universidade de São Paulo e tem um PhD em arqueologia clássica pela Universidade do Texas.

Atualmente, é professor de teologia no Centro Universitário Adventista de São Paulo, onde coordena também os cursos de Letras e Tradução.

DOI: http://dx.doi.org/10.17162/au.v0i2.101

Revista Apunt. Univ.

VOLUMEN V • NÚMERO 2 p. 87 - 112 


\section{Resumen}

El Ion ha provocado reacciones muy diferentes en sus lectores en cuanto al papel de la agenda religiosa de Eurípides. Algunos lo ven, como un intento de socavar la fe en los dioses; otros lo ven como un esfuerzo para mantener la devoción. Es cierto que Apolo no puso todo correctamente en orden y su sabiduría parece estar justificada en el final, pero eso no garantiza ningúna buena intencion inicial por parte del dramaturgo. Mi sugerencia es que lon simplemente parece santo. Él sólo se refiere a la forma de su religiosidad y no a su esencia. Ion se comporta santurronamente porque quiere preservar la integridad del templo que hace cierto grado de poder a su disposición. Sugiero que el tipo de crisis espiritual que lon enfrenta es similar en el Antiguo Testamento a la atribución de Asaf, un ministro en el santuario judío en Jerusalén. De hecho, este trabajo trata de mostrar que el viaje espiritual de lon, es sin embargo, un esfuerzo oportunista para salir adelante. Él no tiene ningún plan o principio moral que no sea convencerse que tiene ese tipo de cosas.

Palabras clave: Ion, Euripides, Asaf.

\section{Abstract}

The Ion has provoked very different reactions in its readers as to what Euripides' religious agenda in the play is. Some see it as an attempt to undermine the faith in the gods; others see it as an effort to uphold devotion. It is true that Apolo does put everything properly in order and his wisdom appears to be vindicated in the end, but that does not guarantee any initial good intentions on the part of the playwright. My suggestion here is that lon merely looks holy. He is only concerned with the form of his religiosity and not with its essence. Ion behaves sanctimoniously because he wants to preserve the integrity of the temple that makes some degree of power available to him. The kind of spiritual crisis I suggest that lon was facing is similar to that the Old Testament ascribes to Asaph, a minister in the Jewish sanctuary in Jerusalem. In fact, this paper attempts to show that lon's spiritual journey is but an opportunistic effort to get ahead. He has no plan or moral principle other than convincing himself that he has such things.

Keywords: Ion; Euripides; Asaph. 
The Ion has provoked very different reactions in its readers as to what Euripides' religious agenda in the play is. Some see it as an attempt to undermine the faith in the gods; others see it as an effort to uphold devotion. Hartigan (1991), for instance, states that "Euripides casts serious suspicion on the ways of the Delphic deity. When the gods of Homeric legend are transferred to the fifth century, they must fail as objects of mortal reverence. A new system is required" (p. 75). Again, she says, "in this play Euripides challenges Apollo's credibility" (p. 69). Similarly, according to Appleton (1927), "the whole purpose of some plays, such as the lon, seems to be simply to discredit the gods" ( $p$. 166). Of course, this reaction is not surprising given the occurrence, in the lon, of the type of iconoclasm that the Old Retainer displays in his dialogue with Creusa: "burn Loxias' sacred oracle!" (I. 974). Burnett (1962), on the other hand, posits that

the Ion is a drama of mortals who have been chosen by a god as his instruments; they do not fully understand the nature of the divinity in whose hands they are, and the revelation of the quality of Apollo's power is the true purpose of the tragedy. (p. 94)

In fact, the play's main characters are caught in a paternity stalemate that seems so irresolvable that it leads the gods to resort to white lies. Burnett (1971) describes it situation like this:

Creusa is thought of as an epikleros, the sole female heir of her father. Normally she should have married the male who was her closest paternal kin so that the royal property would remain in the family, but Creusa had no male relative and so her foreign husband would, according to custom, take on the status of an adopted son in the Erechtheid family. However, neither an epikleros nor an adopted son had testamentary power under Attic law; both could pass property only to their own legitimate heirs by blood; neither could lawfully secure it to an adopted child or even to a bastard unless he were legitimized. In this particular case, then, Apollo's device must be one for securing the legitimization of a bastard, which would have to be done by consent of both parties in the marriage. The bastard is of course Creusa's, but since Xuthus would have no conceivable reason for allowing such a child to interfere with the rights of his potential heirs, he must be made to think that the child is his. Creusa, having recognized it as in fact her own, will not then resist the idea of his legitimization as the son of Xuthus (I. 659-60, where Xuthus looks forward to persuading her of this). Only by this roundabout means could lon legally inherit his portion of the Erechtheid power. (p. 106, n. 6) 
The Ion is therefore one of the plays that raises the problem of how Euripides saw the gods of Greek religion. According to Meagher (1989),

The ancient Greeks had no sacred texts or prophets or formal priesthood with authority to decree official doctrine or discipline. It is, in fact, a misnomer to speak of ancient Greek religion at all. If we are to use the word 'religion' with reference to ancient Greece, we ought to speak of 'religions;' for there were civic, household, chthonic, rural, local, and pan-Hellenic gods and cults, all crowded into ancient Greek piety, not to mention an array of mysteries and brotherhoods complementing or challenging the more traditional beliefs and rites. (p. 66)

So, just like Meagher, I begin with the awareness of the complexity of my subject. It is true that Apolo does put everything properly in order and his wisdom appears to be vindicated in the end, but that does not guarantee any initial good intentions on the part of the playwright. What other end could he write with impunity? Any devout Athenian could look with amazement at the appearance of the patron goddess and be delighted with her good sense. But anyone who looks a little attentively cannot but notice the blemishes on the splendor of Euripides' gods. Apolo himself did not want to appear because he seemed to be afraid people might say mean things to him! There is in fact the notorious accusation of the woman in Aristophanes' Thesmophoriazusae (1. 450-451) that through his tragedies Euripides persuaded men that gods do not exist. Yet, according to Yunis (1988), "the woman is unsubtle in her failure to distinguish which aspects of religious belief are challenged in the work of Euripides" (p. 11). But the accusation by the woman at least implies that "what went on in the mythical society of tragedy, for all of its differences from contemporary Athenian society, mattered for the religious beliefs of individual Athenians" (p. 14).

Indeed, the reason why Euripidean scholarship - just like the woman in the Thesmophoriazusae - cannot come to terms with Euripides' treatment of the gods is that he is strangely unclear about that. At times the gods are passionate defended, but at other times they are abused. As a composer of religious drama, Euripides was controversial in his own time, and remains no less so today. And yet "there can be no doubt that Euripides was a religious man, whether he believed in the gods or not" (Appleton, 1927, p. 165). He echoed in his dramas a multitude of opinions about the gods, and, as Meagher (1989) puts it, his personal religious beliefs remain a matter of conjecture (p. 69). Despite the moral force of his tragedies, we cannot say that Euripides was a moralist. 
It is, upon the view that Euripides is a great attacker of the state religion, a phenomenon to which, as Dr. Verrall (1898) himself remarks, we could only find a modern parallel "by supposing that some eminent Positivist or Agnostic were appointed for one Sunday in every month, upon certain terms of reticence and discretion, to preach the sermon in Westminster Abbey" ( $p$. 81). This is to ask much of our credulity, and Dr. Verrall's theories are really untenable on the assumption that the plays of Euripides, 'abounding,' as he says, 'in sarcasms upon the traditional gods,' were so exhibited" (Appleton, 1927, p. 174).

Besides, the site for which Euripides wrote was closer to a church than a Broadway theater (Meagher, 1989, p. 70). Appleton (1927) convincingly argues that "if he had been regarded as attacking the national religion, he would hardly have been permitted to exhibit regularly at the Dionysia" (p. 174). He explains that Euripides was not against the gods - he was against the religious apparatus that exploited the credulity of the people. There is no more arresting fact in the religion of Euripides than his disgust for the priests and their doings (p. 169). So, in the Iphigeneia in Tauris, we read that it is tragic when one sets aside common sense and puts faith in oracles only to be ruined by them:

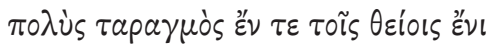

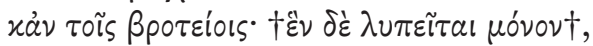

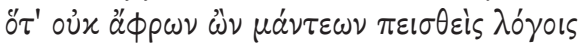

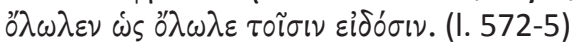

A servant of Menelaus echoes this same attitude in the Helen when he says that prophecy is a vulgar, deceitful and useless occupation:

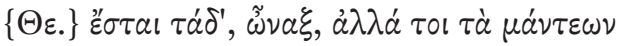

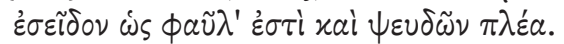

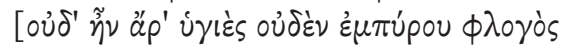

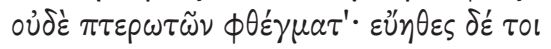

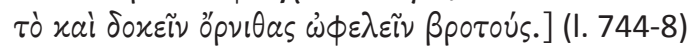

One can account for Euripides' dislike for the oracles - especially Delphi - with a twofold explanation. First, the oracles hated change and strangled the progress of knowledge. Like most manifestations of early religion, "they throve upon human terror: the more binding the terror the stronger became their hold" (Murray, 1912, p. 52). Secondly, Apollo had, through his oracle at Delphi, shown 
a striking favoritism for Sparta all through the Peloponnesian war [cf. Thuc. i.cxviii.3], and it is significant that these attacks upon foretelling are noticeably recurrent in the Helen, which was produced just after the disappointment of the great Sicilian expedition. It is, however, an attack caused, not by a lack of religious conviction, but by very definite convictions - very devoutly held (cf. Helen, I. 1148-50). Admittedly, Euripides's aim is taken not directly at the gods but at their human agents (Appleton, 1927, pp. 171-2). The only religious problems with which Euripides was himself concerned were (1) the nature of the gods, and (2) the conception of immortality (p. 193).

Like Appleton (1927), I believe that this phenomenon of an inconsistent treatment of the gods is familiar enough to all students of Euripides, "and it will not cease to puzzle them until they cease to look in his plays for either an attack upon, or a defence of, the received religion, in so far, at least, as it was anthropomorphic in nature" (p.167). According to him,

Upon the existence or non-existence of these mythological gods he [the average Greek] never reflected. He took them for granted, and was never for a moment concerned with the "reality." With thinking men, however, - and Euripides was one such - the case was far different. But neither were they much concerned with the "reality" of these gods. They had for long known them... not to be real beings, but mere projections of the human mind, 'terms' of unknown value, assumed for the solution of the religious problem. And it was as such 'terms' that they figure in the dramas of Euripides. He deals with them - criticizes and examines them - as such, but with their existence he has no concern [cf. Iph. Taur., 386-91]. (p. 169)

According to Meagher (1989),

it may be justified, though not kind, to say of this endeavor to disclose the true mind of Euripides what was said of the notorious "search for the historical Jesus," namely that each critic, staring down into the well of history to catch a glimpse of Jesus' (read Euripides') own countenance, eventually with an elated sense of discovery glimpses his or her own face. (p. 78)

That is why my intention here is not to mainly dwell upon the way Euripides treats Apollo. It is not his personal spiritual journey that has captured my interest. My purpose is to assess Ion's treatment of the gods. It is important to evaluate Ion's handling of the gods because (1) what an Athenian spectator saw the tragic hero believing about the gods was pertinent to what he himself 
believed about the gods, although the beliefs of an Athenian and the tragic hero should not be considered equivalent (Yunis, 1988, p. 15); and because (2) a consensual interpretation in Literature is always baffling, and there has been an overwhelming consensus that lon's spiritual journey is one from sanctimoniousness to one of loss of innocence. This unanimity has made him a shallow character unworthy of Euripides' genius. Whitman (1974), for instance, sees him as an "innocent, rather sanctimonious young temple servant" (p. 89).

Despite this consensus, I'd say that lon is not a petty character. My suggestion is that he had been facing a spiritual crisis long before Creusa presumably set the whole plot into motion. The movement of the play is in fact marked by the guilt and suffering of both lon and Creusa. Creusa's guilt, fos instance comes in the form of her many implied mentions to the ekthesis of Ion, especially the place where it had happened: the aêdonios petra ("the nightingale rock", I. 1482) and the antron erêmon ("the desert cave", I. 1494), which pervade the whole tragedy (Huys, 1995, p. 174). So, my intention here is to question assertions such as Owen's (1939) that a "pious young votary of Phoebus becomes the mouthpiece of Euripidean views, hardly appropriate to his character or office" (pp. 436-40), because, against Yunis (1988, p. 129), I do not take lon to always mean what he says.

\section{Ion as Servant of Apollo}

The odd nature of Ion's persona is first stressed by the very duty he is described as performing in the Delphian sanctuary as well as by his social status in that religious center. In fact, no one knows exactly what kind of staff he was in the pecking order of the temple. He is described in different ways:

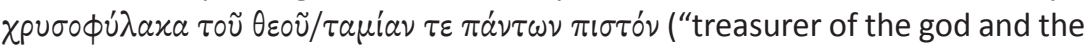

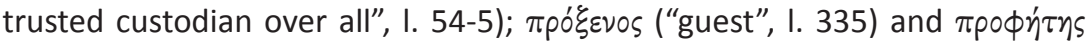
("prophet", I. 413-6). Some argue that Ion's religious function is prefigured in Hermes' characterization of himself as $\delta a l \mu o ́ \nu \omega \nu ~ \lambda a ́ \tau p เ \nu$ ("the runner of the deities", I. 3b-4). It is clear at least that lon is the one responsible for sweeping the temple's floor and for shooing the birds away from it to prevent defilement. Despite that fact, Yunis (1988) complains that "some of Ion's duties in Delphi are appropriate to his status as temple-slave, other duties, of high responsibility, seem inappropriate" (p. 122). Because of that, we can say that no single term suffices to cover the range of activities that he performs. Jordan (1979) describes a generic office that he calls "precinct governor" (pp. 23-28), and which would include officials of various titles. According to Yunis (1988),

Revista Apunt. Univ. VOLUMEN V • NÚMERO 2 p. 87 - 112 
however, "such officials, of ultimate responsibility for the sanctity and safety of the precinct, would hardly be slaves" (p. 122, n. 40). Bömer (1961, p. 46, n. 1) argues compellingly against the appropriateness of classifying lon as a $\nu \varepsilon \omega x o ́ p o s$ ("warden of the temple"), as many have done. The term appears nowhere in the play. Neither can we call lon a priest, because in the descriptive division made

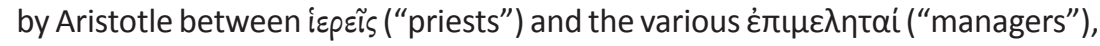
Ion would decidedly fall with the latter (Pol. 6.1322b18-29).

Slavery, both factual and figurative, is a focal point of the tragic theater. Ion is undoubtedly a slave in Delphi, and this is an important fact for Euripides' Athenian audience. Slavery was a central institution of the classical Athenian polis: only the most impecunious citizen could not find the money for a slave at all. According to Edith Hall (1997),

through some recurrent types of plot-pattern tragedy affirmed in its citizen spectators' imaginations the social world in which they lived. The focus is on three types of pattern - plays in which male Athenian performers represented (i) mythical Athenians interacting with outsiders, (ii) women, (iii) significant slaves. (p. 93)

So, in the Frogs, the comic poet Euripides asserts that his tragedy is democratic, since it gives voice to women and slaves (I. 949-52). "The fictional representatives of these groups, silenced in the public discourse of the city, are permitted by the multivocal form of tragedy to address the public in the theatre as they never could in reality" (Hall, 1997, p. 93). Creusa is therefore a fitting representative of the process of attribution of voice to a tragic woman. "She has not stayed at home, as the woman of tradition (the woman of Apollo's plan) would do, but has come to Delphi like a weaker Neoptolemus, half intending to confront the god with his injustice" (Burnett, 1971, p. 104).

Several characters, particularly in the Trojan cycle, lose former aristocratic status and become slaves, a fate looked upon in the tragic space as especially hard to accept. But even though one of the most frequent forms of peripeteia ("reversal") is actually peripeteia of status,

the tragic texts everywhere assume that the slave/free boundary is as fixed, natural, and permanent as the boundary between man and god. It was necessary to the perpetuation of institutionalized slavery to foster a belief in the natural servility of those born into the slave class, and no character in tragedy proposes abolishing slavery. (Hall, 1997, p. 112) 
This explains why although the move from aristocracy into slavery is quite common in tragedy, the tragic theater never allows the movement from slavery into aristocracy. In fact, the only possibility for lon to ascend to an aristocratic status is for him not to have been low born.

Another driving force behind the plot of Euripides' Ion is cultural apprehension about the influence of slaves upon free members of the household, in particular women (Hall, 1997, p. 115). We can perceive such anxiety since the moment Creusa admonishes lon to be silent about the conversation she had had with him, while her husband was away:

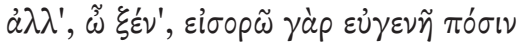

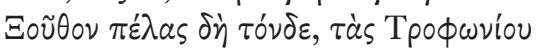

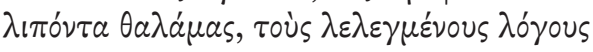

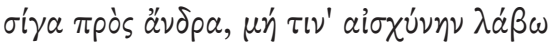

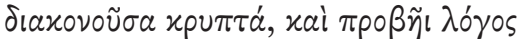

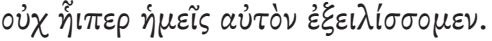

The plotting scene likewise stems from the same restlessness concerning the dangerous effect of scheming slaves on vulnerable women when such women lack the judgment of free men to guide them.

So, Apollo must liberate Ion from potential accusations of low birth and bastard status. But in order to bring him to enjoy aristocratic privileges in Athens, the god has to resort to a very intricate scheme. He manipulates Ion, Creusa and Xuthus through a quite vague oracular utterance.

\begin{abstract}
Although we are told the god's response only indirectly, via Xuthus' interpretation, there is no doubt that the words are deliberately ambiguous and thus deliberately deceptive, and, as Xuthus was to understand their meaning, patently untrue. But how easily man may be deceived by the god! The oracle is interpreted as each wishes it to be: Xuthus has a son, lon a father, and, if not identified at least a possible mother and the prospect of Creousa as his stepmother. The ambiguity of the god's words promote the self-deception of each character. (Hartigan, 1991, p. 76)
\end{abstract}

We are given no verbatim report of the oracle, and we can only make guesses based on Hermes' disclosure (69-73) and Xuthus' report of it (I. 530537). In fact, "we are more displeased with the confusion resulting from Apollo's ambiguous words than with the grieving queen" (Hartigan, 1991, p. 81). For that reason, Yunis (1988) comes to the conclusion that "Apollo has told, at minimum, 
a white lie", and for Apollo to lie "even to this degree suffices to render lon's predicament serious and not frivolous, founded on a real act of deceit by the god and not caused by a misunderstanding of silly, rash Xuthus" (p. 135, n. 64). The rationale for this statement is that some think "Ion's stern moral sensibility holds Apollo to a severe standard" (Yunis, 1988, p. 135, n. 64). But I would like to suggest that it is true for a different reason. Since the beginning lon gives us some indications that he has never actually committed himself to the service of the god. He ministers at the temple because that is his job. He cares about the physical space in the sanctuary, but his religion is entirely nominal. Apollo's lie is a problem to him because he was already displeased at the behavior of the gods towards men. He thinks that the gods are unfair and that they hold a double standard with which they judge men's actions and their own (cf. I. 436-47). The real reason why lon toils so hard at the temple service is that he knows that that is his only source of power, and his only hope for a privileged life in the highly stratified society of his time and country. He knows he is a slave, but he is not satisfied with that. He feels relatively comfortable at Delphi and he is not willing to sacrifice that for any dubious proposals from others (cf. I. 633-9). But before we can assess his quest for more privileges, we must first address the question of how religious he was, and that is what we will do next.

\section{Ion's Religion}

As previously stated, I have problems with the overwhelmingly unanimous view that lon is entirely devoted to Apollo from the start. According to Burnett (1970), for instance,

his unworldly childlike purity is the subject of the song that marks his first entrance, at the dawn of his drama's day... The Delphic setting gives oracular proof that the child who was exiled long ago has had a happy fate and it announces that this play will concern itself with what the boy is leaving behind, as well as with what he is going to claim. (p. 104)

Likewise, according to Hartigan (1991), "for lon the tending of the temple and the guarding of its gold (I. 54-55) is not just a job but the thing which gives meaning to his life" (p. 70). In this view, the words of the chorus serve to highlight, by contrast, Ion's reverence to Apollo: "its interest in the site is superficial, his is intense and personal" (Barlow, 1971, pp. 22-3). If this is so, then Whitman (1974) is correct when he says that Ion "is almost pathetically happy in his task" (p. 75). 
To support this claim that lon is a sanctimonious boy totally immersed in his innocent belief in the workings of providence, Yunis (1988, pp. 133ff) lists a few occasions when lon supposedly demonstrates his continued allegiance to his god in face of trying circumstances:

a) Ion repudiates Creusa's attempt to put her question to the oracle (I. 369-80) for the sake of avoiding even the possibility that Apollo

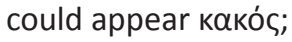

b) Ion submits to the distasteful necessity of acknowledging Xuthus as his father, the man he had just been threatening with murder (I. 522-7);

c) Ion narrowly escapes the death plotted for him by Creusa because at the crucial moment he was attentive to pious procedure;

d) Ion refrains from seizing the impious fugitive Creusa who has occupied Apollo's altar;

e) when lon's birth tokens are finally placed in his hands, he is first inclined to dedicate them unopened to his god (I. 1380-4).

Also according to this view, lon's initial refusal to go to Athens is due to his resistance to jeopardize the blissful religious experience he enjoys at Delphi:

If Creusa is indeed telling the truth... the god would be кakós, lon's noble devotion and pious service to the god would have been unworthily bestowed, and the greatest prize of his reciprocity with the god, a sense of just association, would vanish altogether. The ties of allegiance between the mortal and the god would not merely be spoiled but mockingly debased. (Yunis, 1988, p. 135-6)

These words are an echo to what Burnett says about lon's reaction:

Because of the peculiar nature of his fate until now, because he has been so favoured, because of Apollo's graciousness, in other words, lon is blissfully happy exactly where he is. His monody at the beginning of the play voices a sense of well-being mixed with ecstasy that is shared by no other creature of the Attic stage... he knows that it is partly the purity of Delphi that ministers to his joy... he has invented the pretty 'fiction' of being the god's son, and this means that he has fixed all of his curiosity as to his actual parentage upon his mother. He is not nearly so pleased at discovering a mortal father as he should have been, and he longs still for the sight of the woman who bore him (Burnett, 1971, p. 107). 
So, according to Hartigan (1991), "Ion's faith in Apollo is complete and is the source of the joy he finds in his life at Delphi" (p. 71). Ion can only agree with the journey to Athens when in reality his innocence has already been corrupted:

He does not want to leave Delphi... He can still be innocent at Delphi, if he goes to Athens, which he calls kathara, "pure" (I. 673), he will be a foreigner, that is to say, a defilement... he will defile the purity of Athenian blood, while Athens, with its touchy passions and politics, will corrupt him. He does not want to go to the big city. But the big city has come to him, and the more he gets involved in its passions and the drive to act, the more he begins to partake of them, until he loses his innocence, once and for all, in the attempt on his mother's life (Whitman, 1974, pp. 90-1).

It is unusual to talk about character development in ancient tragedy, especially one whose whole action takes but a day. Despite this fact, Burnett, Whitman, Yunis, and Hartingham have all seen this play as a Bildungroman of Ion's loss of innocence. Because of that, Whitman (1974) states that "when that [the recognition scene] is finished, we see a new lon; the sanctimonious boy is gone, and a real young man is ready to enter upon his life" (p. 92).

On the other hand, this view holds that this loss of innocence does not necessarily entail a movement away from his piety, because while "his words reflect his faith and arise from his innocence... later in the play his belief will prove to be well founded" (Hartingan, 1991, p. 71). Yunis admits that lon is confused at times, but he acknowledges no possibilities for him to be disloyal to the god or to his faith.

After enduring what had seemed like a total renunciation of the gods' concern for him, Hippolytus soberly accommodated himself to the limited reciprocation Artemis could offer. Hippolytus was never inclined to question what Artemis was; that was and remained crystal clear. Ion differs from Hippolytus in that he tends to reflect upon his relationship with Apollo, and to use his powers of reason to understand that relationship. Ion gradually becomes confused about the moral disposition of the god on whom he has always depended for both livelihood and purpose in life. He senses that the trust upon which his extraordinary allegiance to Apollo is founded has been betrayed. Yet amid the growing uncertainty lon remains steadfastly loyal. (Yunis, 1988, pp. 121-2, cf. I. 1537-8) 
Also according to him, "Ion's relationship with Apollo... stands the test of circumstances" (p. 127). This position implies that lon's godliness is the main source for his spiritual predicament: "the dimension of moral sensibility added to the normal expectations of pious worship is the essential factor in the bewilderment lon experiences later in the play." (p. 126)

Ion's faith then becomes emblematic of the entire religious system that operates at Delphi, thus explaining why it is impossible for one to identify a specific office that he may hold there or - contrariwise - to see him as an amalgam of religious functions. In any count he is more than those possibilities. He is the incarnation of the spirit of Apollo's cult:

If only by sheer force of personality, lon combines the various recognizable details of temple service in a unified spirit of devotion to Apollo. What emerges from the picture of his temple service is not an amalgam, realistic or otherwise, of religious tasks, but a single, dedicated worshipper of the god. (Yunis, 1988, pp. 122-3)

My suggestion here is that this view is not accurate. Ion merely looks holy. He is only concerned with the form of his religiosity and not with its essence. Ion behaves sanctimoniously because he wants to preserve the integrity of the temple that makes some degree of power available to him. Could it be that he would not care for Apollo to appear xaxós if that would not in some way make his own position vulnerable at Delphi? Could it be that he acknowledged Xuthus as his father when he learned that he would profit from doing it? I believe so. And so was he attentive to the temple's procedure when Creusa acted as a suppliant, and so was he inclined to dedicate his birth tokens when they were handed to him. Ion did not want to incur in any profanation of the temple that fed him, but he was willing to take the necessary measures for assuring his own supremacy when the moment called for them.

I acknowledge that the expression of one's religiosity may not be the same today as it was in antiquity. But, even if we allow that the mere display of one's religiosity played a greater role in the appraisal of one's sincerity in the ancient Greek world - what does not seem to be true -, it strikes me that Ion's concern is excessively directed towards a profession of faith in its most peripheral aspects.

The kind of spiritual crisis I suggest lon was facing is similar to that the Old Testament ascribes to Asaph, a minister in the Jewish sanctuary in Jerusalem. He authored many of the psalms of the Book of Psalms, and one 
in particular exposes the doubts he had about his own spiritual standing. He had been born during King Saul's reign, one of the darkest ages in the spiritual history of ancient Israel. He was a Levite and that meant he was supposed to be a minister in the sanctuary. When David became king he established an elaborate liturgy in Jerusalem and Asaph was appointed chief musician (cf. 1 Chr. 15:16-7, 16:4). In fact, Asaph became as famous a musician as the king himself. He was a talented conductor and exerted the kind of spiritual leadership that brought him the title of "seer" (cf. 2 Chr. 29:30). However he ended up overwhelmed by the very demanding task of leading the choir and orchestra. He became spiritually exhausted and - although he was a minister in the sanctuary - he offered the Godhead only a nominal worship. Psalm 73, which he wrote, attests to his spiritual difficulties. He became envious of the wicked, and resented the fact he was not as powerful as they were:

For I was envious of the arrogant; I saw the prosperity of the wicked. For they have no pain; their bodies are sound and sleek. They are not in trouble as others are; they are not plagued like other people. Therefore pride is their necklace; violence covers them like a garment. Their eyes swell out with fatness; their hearts overflow with follies. They scoff and speak with malice; loftily they threaten oppression. They set their mouths against heaven, and their tongues range over the earth. Therefore the people turn and praise them, and find no fault in them. And they say, 'How can God know? Is there knowledge in the Most High?' Such are the wicked; always at ease, they increase in riches. All in vain I have kept my heart clean and washed my hands in innocence (vv. 3-13).

Interestingly, even when he was completely overwhelmed by his doubts, he did not move away from his duties in the sanctuary: "When my soul was embittered, when I was pricked in heart, I was stupid and ignorant; I was like a brute beast toward you. Nevertheless I am continually with you; you hold my right hand" (v. 21-3). And - like lon - he is worried about not jeopardizing the prosperity of the temple he serves. So, he chooses his words to refrain from revealing his spiritual discomfort. "If I had said, "I will talk on in this way,' I would have been untrue to the circle of your children" (v. 15). His predicament is only resolved when he wholeheartedly embraces the service in the sanctuary: "But when I thought how to understand this, it seemed to me a wearisome task, until I went into the sanctuary of God; then I perceived their end" (vv. 16-7). Once his spiritual dilemma is solved, Asaph makes a strong declaration of faith in his God: "You guide me with your counsel, and afterward 
you will receive me with honor. Whom have I in heaven but you? And there is nothing on earth that I desire other than you" (vv. 24-5).

Even when Hermes describes his devotion in the beginning of the play,

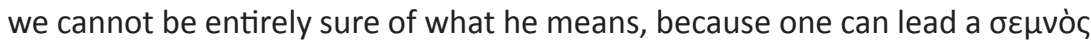
Bíos without being sincere about it:

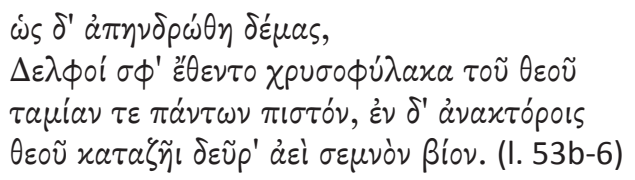

Because lon's statement of his own holiness happens relatively early in the play, many have believed it to refer to his dealings with the god, but, in fact,

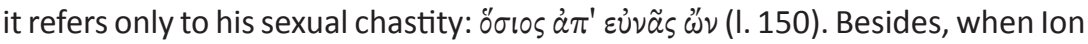
vehemently defends his own devotion while trying to slay Creusa at the god's altar, he does so only because Creusa has firmly stated that he belongs now to his new father and not to the god. She claims she is the one who actually belongs to him. Her intimacy with the god would lead us to believe so - were it not the consequence of a rape! She claims to belong to the god when she does not. Likewise, lon makes an equal claim when he does not belong to the god any more than she does. According to the boy, he came to belong to his earthly father, while he was the property of his divine father:

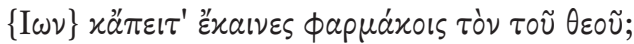

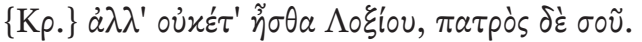

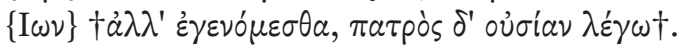

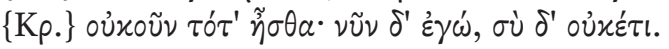

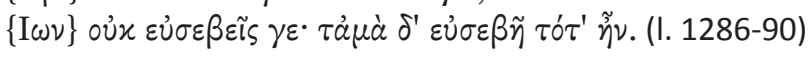

Both claim to be the god's. And both intimately know they are lying. The irony is that, in fact, mother and son do belong to Apollo. The god possessed her in bed, and possessed him as both his slave and offspring.

On the other hand, Ion's emphatic repetition, in his prayer to Apollo, of his appreciation for the tasks he performs in the sanctuary is representative of his mental - maybe unconscious - effort to convince himself of that. First, he states why he thinks the humble tasks that he is carrying out are of real importance - he serves gods not mortals: 


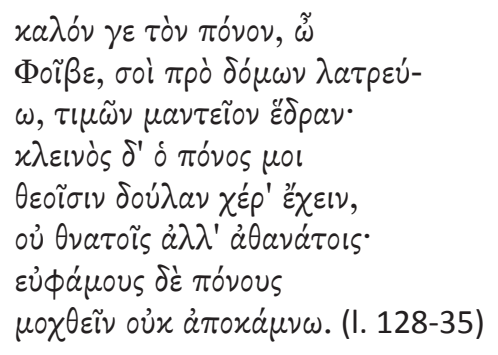

When he is about to finish the sweeping of the temple's entrance, he laments that he has finished his chore because he understands that his sustenance comes exactly from performing such a task. But he is willing to find a better destiny, if that is altogether possible:

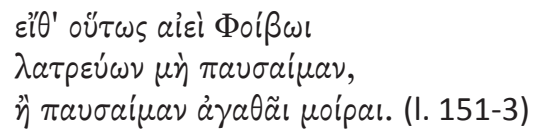

Finally, he concludes his prayer saying that he will not betray the temple that feeds him. He acknowledges here that his service to the god is a compensation for the benefits he receives from the temple.

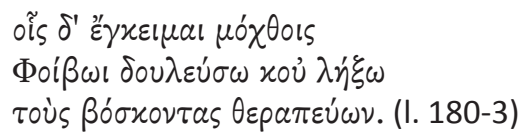

In fact, he had already hinted at that before starting his prayer to Apollo while he was instructing those under him about the chores they were supposed to get done:

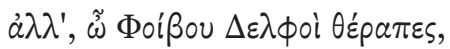

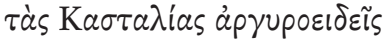

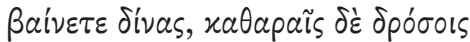

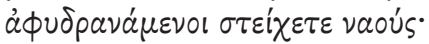

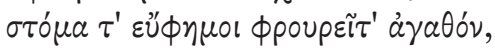

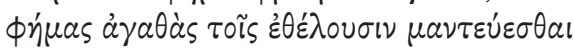

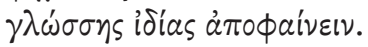

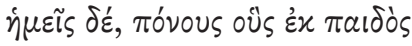




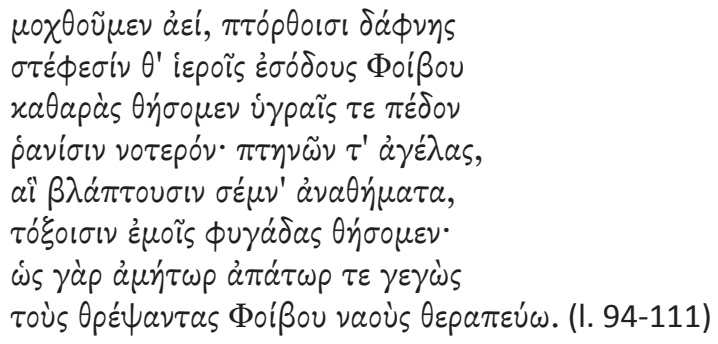

Even here, lon vents out frustration when he says that he serves the temple simply because he eats from it. And to remain alive he is content to sprinkle the floor and wipe it clean from bird droppings. Besides, when lon is touched by Creusa's restlessness at the gates of the temple at Delphi, and then expresses his discomfort about her evident pain, he does not include himself among those who take pleasure at the sight of Apollo's shrine:

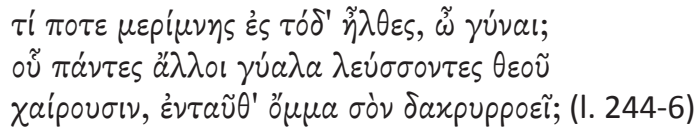

Could that indicate that he has actually had enough of the works he is nominally praising? After all, when talking to Creusa - then a stranger -, lon presented himself as a slave of the god. It does not matter how many fantasies he might have had about his relationship with Apollo. He is the god's slave. He knows that, and he does not hide it. And that is a reason for Creusa to pity him:

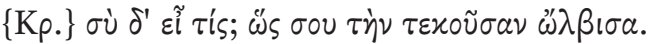

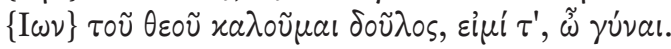

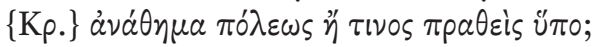

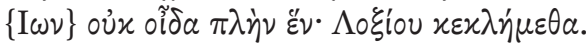

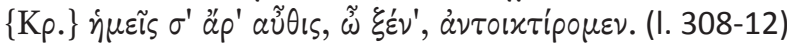

So, even though lon enjoys the privileges that his pious life grants him at Delphi, that comes with a price. He is willing to pay it, however. He knows there are no other options for him:

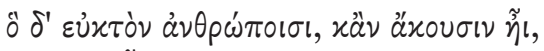

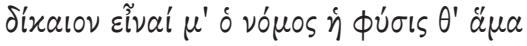




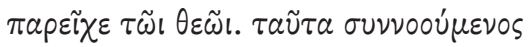

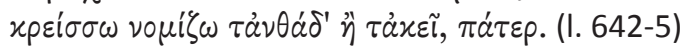

Here, Ion admits he thinks about his shallow life. But he carries on with it; because he knows he has no better option. What makes lon tick is the privilege of being in charge at Delphi while living a life of relative "leisure" ( $\left.\sigma \chi 0 \lambda \eta^{\prime}\right)$. This is the closest that he can get to enjoy the privileges of aristocracy:

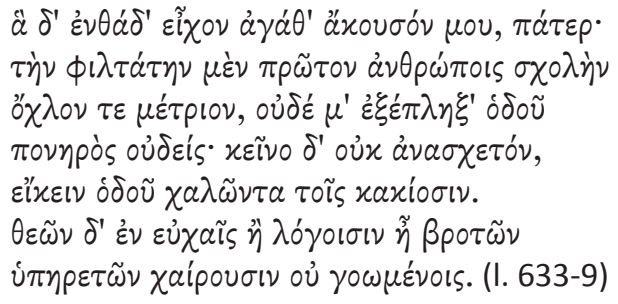

In this passage Ion considers it intolerable to yield the road in deference to inferiors. That shows he has a craving for aristocracy. In fact, his career in the temple may lead him to a quest for power.

\section{Ion's Quest for Power}

Burnett (1970) suggests that lon is only sixteen years old (p. 126). It is true that he performs humble tasks that would perfectly fit a younger age, but I think he is probably older than that; otherwise he would not be in charge of other more serious responsibilities. Even though I acknowledge that his quest for power is nowhere explicitly depicted in the play, I would like to suggest the alternative reading which takes lon not as the sanctimonious Mr. Devout, but as a young boy who is inebriated by the power he has amassed at Delphi despite his theoretical humble origins. He is not self-righteous or obtrusively virtuous, but is only clinging to the one means available for him to continually benefit from the privileges he enjoys at Delphi. I feel more confident in saying so because the Ion is proverbially a play that has been marked by "sad, even abysmal, misinterpretations" (Whitman, 1974, p. 70). The confusion is so generalized that I am confident that if I err here the state of things will not be worse, but if I succeed, it will certainly be less confusing.

Hartigan (1991) hints at that when he admits that at some point lon "reveals the real reason for his aversion to going to Athens (I. 634ff). At Delphi 
he is a man of power, respected and needed by all who approach the temple, nor did he have to mingle with hoi polloi (I. 636-637)" (p. 77). In fact, supremacy is one of the main themes of the play, since the lon is recognizably a "drama of return to wealth and power" (Burnett, 1962, p. 101). In the play, lon must decide if he prefers to have limited power at Delphi, or full power in Athens. A decision will only come, however, when he perceives that that is the case.

Although Yunis (1988) accepts that there is "a certain economic reciprocity between Ion and the god to which Ion gives clear, repeated expression" (p. 123), cf. I. 110-1, 137-40, 183, he downplays its importance by asserting that such economic ties are only made possible by lon's "affection, devotion and, finally, a sense of justice" (p. 123). So, according to this view, it is not chiefly because the god feeds lon that he is led to call him "father," but because, in his solitude, his intense and intimate feelings of loyalty to the god lead him to claim metaphorically the distinctive relation of kinship with him (cf. I. $136,139)$. So, pious service, slavery, and filiation are all involved in lon's situation with regard to Apollo. But, according to the predominant interpretation of the Ion, all of this revolves around his unshakeable faith in the god.

But there is again evidence that lon was not as credulous as we might suppose. There are a few cruces that can only be satisfactorily explained if we admit that lon had a spiritual crisis. First, why is he so forcefully attracted to Creusa when she so openly blames Apollo for her misfortunes? In fact, "Creusa's rebellion, her lack of faith, have expressed themselves in her fiction of the baby devoured by birds" (Burnett, 1971, p. 121). Later on in the play she directs vehement accusations against the gods, calling them "unkind betrayers of beds":

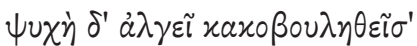

$\varepsilon^{\prime \prime} x \tau^{\prime} \dot{\alpha} \nu \theta \rho \omega \dot{\omega} \pi \omega \nu$ हैx $\tau^{\prime} \dot{a} \theta \alpha \nu \alpha \dot{\tau} \tau \omega \nu$,

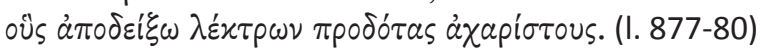

She even calls Apollo a "vile seducer" (xaxòs घủvátwp, I. 912). However, every time she retells her story, she presents Apollo in a more favorable light. In fact, according to Yunis (1988),

Nowhere in the play is Apollo faulted just for having seduced a mortal woman; sex between gods and mortals was of course not unusual in the legendary world to which lon belongs. As he had suggested earlier (I. 355), what lon could not abide was the thought that the god had abandoned the mortals with whom he had established connections. Creusa herself had complained 
not of the rape, but merely of the fact that Apollo abandoned her (I. 384389)... This repudiation amounts to a failure to maintain reciprocity. (p. 131)

Yet, that does not mean that sex with a god was a carefree experience. The record abounds with references to the suffering that resulted from these affairs, as in the case of Cassandra, Coronis, and other maidens (Kearns, 2013, p. 57-67).

Secondly, why is it that lon never inquired the god about his father even though he lived in the temple where the national oracle of Greece was supposed to elucidate all mysteries of life? Why is it that when Creusa gives vent to her reprimand against the god, Ion immediately starts reproaching him? Why is it that the boy who boasted at noon of the purity of his Delphic life, is tempted at evening to desecrate the altar of Apollo?

First, Creusa's prompt and powerful attraction over lon has been explained in different ways. Whitman (1974) sees it as a case of filial instinct that works in conjunction with a reasonable impression caused upon the young man by Creusa's aristocratic bearing:

Ion himself, in his first meeting with her, feels powerfully drawn toward her, despite the fact that she speaks nothing but evil of his own god, Apollo. Perhaps this should be looked upon as instinctive filial feeling, which may work mysteriously even in ignorance, but it is also clear from his first speech that lon is struck at once by her intrinsic qualities. (p. 83)

Secondly, lon's lack of initiative concerning an inquiry about his real parents is explained on basis of his absolute naïveté and fear of being baseborn:

Creusa's search has also a further function: it eventually sets lon's in motion. The young sheltered temple servant had often wondered who his parents were, but had suffered no driving need to find out. Creusa asks him, rather naturally (I. 328), "Have you never sought out your origins?" And we too are prompted to wonder why he has not. His reply, that he had no clue or token to go by, is not very satisfactory; for even though he had no clue, it seems strange that a foundling youth brought up in the very precinct of Delphi, and having a Pythia for a foster mother, should never have been moved to ask the oracle who he was, or how he might find his parents. Obviously, the plot offers one reason why he could not have done so, and there is a suggestion (I. 325) that he may have feared, as he later does, to discover that he was baseborn. But character offers the chief explanation: Ion is remarkably innocent young man when the play opens... In his utter ingenuousness, he has been content 
to think of Apollo as his spiritual father (see 311), and he calls him "father" in deepest reverence, never dreaming of the ironical truth. (Whitman, 1974, p. 85)

Thirdly, Euripidean scholarship has been so puzzled about lon's early reproach of Apollo that it has sought to justify it in different ways. The context shows Creusa telling Ion her story as if it had happened to somebody else. She

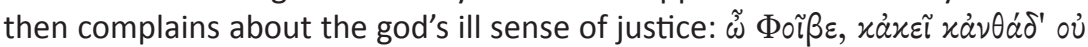
$\delta$ '́xalos हĩ (I. 383). Her confidential conversation with lon is interrupted, however, by the arrival of Xuthus. As soon as the couple leaves, Ion then feels the need to address Apollo and complain that the god ravishes girls and betrays them, secretly begetting offspring and heartlessly leaving them to die:

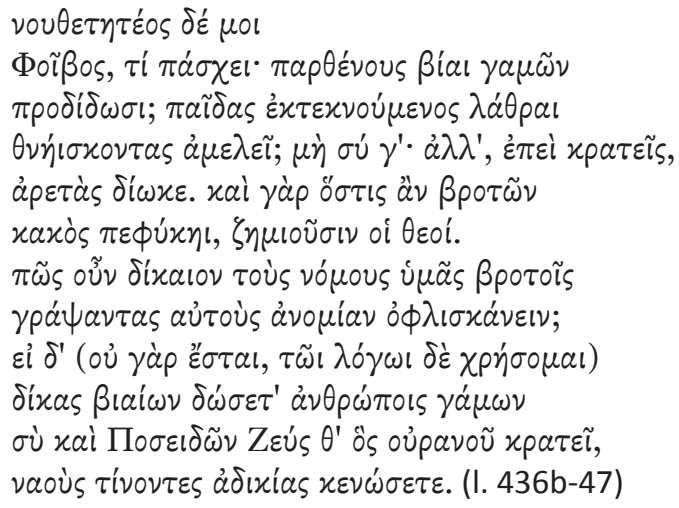

This passage is so far from the predominant view that lon is a sanctimonious boy who is incapable of questioning any of the religious dogmas of Delphi, that some have sought to undermine the seriousness of lon's words here. Yunis (1988), for instance, calls it an "admonishment passage" and understands it as "a friendly chiding" (p. 130). According to him, lon speaks in virtual privacy, and his reflections would not run the risk of embarrassing the god and undermining his cult. For him, lon feels no personal involvement with Creusa and her problems (cf. I. 433-4), and is therefore unlike to give credence to a story he does not fully understand, heard from a woman he does not know. In this case, his admonishment would be nothing more than an afterthought to his pious service. Burnett (1970) goes even further in undermining lon's earnestness here, when she says that "the boy is playful in his reproach." 
However, Ion's reproach does not sound playful at all. He seems well aware that the gods are not to be trusted. He refers not only to Apollo's rapings and whorings but also to Zeus' and Poseidon's. So, it cannot be that only Creusa's case has caused him to make such a vehement rebuke against the gods. He is aware of other situations in which the gods had not acted properly, although he never mentions them. Besides, the only reason he posits a judgment day for the gods but then acknowledges he is just making an absurd supposition is that he is afraid the gods might overhear him - and that he might lose his job or suffer even a worse fate! Despite that, his conjecture comes very close to being a wish. It is exactly because lon speaks in virtual privacy, there is no reason why we should not believe him. Since he feels, at that point, no personal involvement with Creusa and her problems, we should take him seriously. He is not addressing Apollo out of rashness. He is just expressing what he has kept in his heart. We can see that he is in fact outraged, and reveals that he does not trust the gods. That is tantamount to saying that he serves them out of fear.

What Burnett (1971) says about Ion after the suppliant scene (cf. I. 1312-9), when he had his arm raised against Creusa, can very well be applied to him this early in the play: "now he has succumbed to the world, and he thinks of an Apollo so shrunken in stature, so parochial in power, that he needs human censors to watch him and human guardians for his divine purity" ( $p$. 120). This is his sentiment throughout the play, and that is only changed when he realizes that Apollo is, in fact, his father.

Finally, Creusa's suppliant gesture formally makes of her pursuer an exact replica of herself, a mortal who would blaspheme in action by attacking one of Apollo's creatures upon consecrated ground (I. 1284-90). The predominant interpretation of the play sees here "the fullest measure of the change that seems to have been wrought in lon by the day's events" (Burnett, 1971, p. 120). Most scholars are puzzled at what seems to be a radical transformation, and "many critics have rejected it as wholly against nature and therefore bad characterization, while others have tried to deny lon's plain intention to seize a suppliant woman" (p. 121). Norwood (1942) sees it as "crude psychology" (p. 111), and Wilamowitz (1926, p. 150) understands that lon could criticize the right of asylum but could not, brought up as he was, raise his hand against it. However, as in the case of Ion's reproach, in I. 436-47, there has been no transformation. Ion has no special concern for the gods. He worries mainly about the physical space of the sanctuary. He cares for his job, not for his boss. For him, as things stand, the good and the bad are not distinguished, receiving equal treatment from the gods: 
$\{\mathrm{I} \omega \nu\} \phi \varepsilon \tilde{v} \cdot$

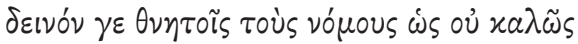

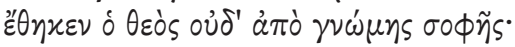

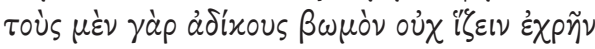

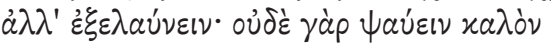

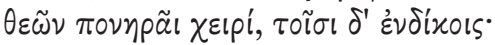

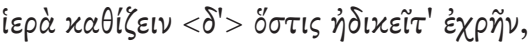

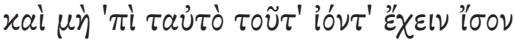

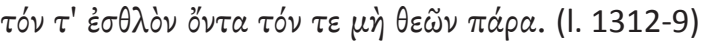

Ion's economic reciprocity with the god is, in fact, the determining feature of their relationship. It is the temple that feeds and dresses him. His very clothes calls one's attention to the advantages Apollo's treasurer can have over other people:

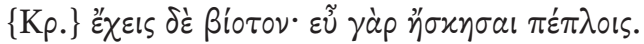

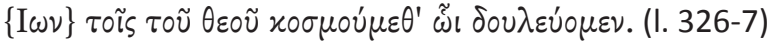

The boy is also well aware of the modus operandi of the sanctuary. He knows the way politics works in the temple, and he can make informed guesses about the outcome of inquiries, but - most of all - he knows that, no matter what the question is, the answer will always foster the interests of the temple:

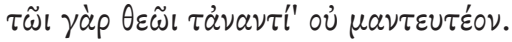

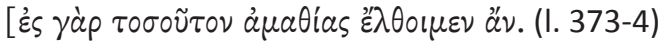

Ion's obsession for power is first revealed when he realizes that attachment to Xuthus implies a Delphic birth, a free-born mother, and consanguinity with Zeus, and then consents to listen to the claims of this importune man who alleges to be his father.

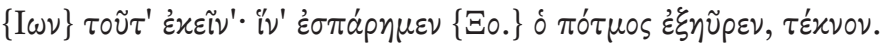

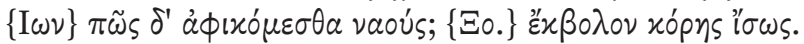

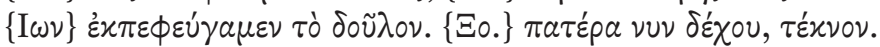

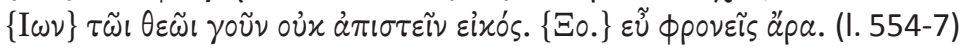

It is only when lon is convinced that Xuthus is his father that he claims that is not right for him to distrust the god. But at whom is his mistrust directed 
here, Xuthus or Apollo? Probably, both. In Xuthus' case, Ion's mistrust is only justified by Xuthus being so gullible. On the other hand, Xuthus is the only character in the play that could accuse Apollo of lying, and the only one whom Apollo is justified to have possibly lied to. After all,

"People get the gods they deserve..." Why inflict truth on a man who has so little concern with it? For it has been rightly observed that the delusion is in character for Xuthus; he gets, in a way, the "truth" he deserves (Whitman, p. 1974, 81).

Likewise, the joining together of Apollo to a mortal woman, which he found to be so disconcerting before, appears in a more hopeful light if he himself is the result. When Ion later recognizes Apollo's paternity, he is happy with it.

Whitman is right when he points out why lon seems so reluctant to go to Athens: "he must renounce his Apollonian life at Delphi, with its simplistic piety and its lack of commitment, where he has felt so complacently at home" (p. 90). In this regard, Derrett (2012) questions what lon might have gained if he had repudiated Creusa and Xuthus. "A near sinecure for life?" (p. 266). Despite his professed skepticism of kingship (I. 621, 632), the boy knows that he has much more to gain if he discards the temple and moves on to Athens. Ion's piety is a façade. It lacks real commitment, and is more straightforward than it looks: he works for the best pay.

\section{Conclusion}

It is easy to understand why Euripidean scholars are so prompt to accept the view that lon undergoes a loss of innocence in the play towards attaining his own maturity as a man and a citizen. After all, "shattered innocence is a frequent theme in most Euripidean drama" (Whitman, 1974, p. 94). But, in this play, that is too easy an alternative. If we conceive lon as a young man facing a spiritual crisis that prompts him to lead a double life, then his character becomes more complex and the plot is enriched. According to Whitman, "Ion, before the play ends, is in search of himself, a fact that precludes the label melodrama" (p. 70). This search, however, does not take place only at the end of the play. It occurs throughout the drama, culminates at the recognition scene, and there finds resolution. Even if the explanation Burnett (1971) proposes to save Apollo has a slight ring of truth to it, it does not eliminate all the complexities concerning the god's actions. According to her, 
The trick about this rescue is that, where others require as a rule three phases - recognition, intrigue, and escape - this one is entirely accomplished within the recognition... In one moment of comprehension she [Creusa] sees that this is the point to which her whole life was leading, that all was necessary as preparation for this. She sees that there has been no cause for fear, that neither she nor her child has ever been abandoned, but that both have been constantly under Apollo's watchful eye. (Burnett, 1971, p. 123-4)

But are we really justified in thinking that Apollo acts in the play moved by Creusa's encroachment? Could we not alternatively imagine that he acts because he understands that lon's lack of commitment needs his saving intervention? If Ion was but superficially touched by the liturgy of the Delphian temple, would the powerful god be content with that kind of profession? Wouldn't he be expected to intervene somehow? If we see him under this light we might solve another crux proposed by Burnett (1971):

Many moderns have been bothered by the mechanical importance of Apollo in this play. He is defined sometimes as an irresponsible divinity, sometimes as a mere mask for disorderly chance, but he is considered all to [sic] frequently to be external to the human action and therefore unjustifiable as a cause. This attitude springs from the modern inability to think mythically, and from the modern assumption that Euripides must have shared with us the limitation of imagination which we call "healthy skepticism." The fact is, however, that the poet has made for this play a god of undoubted power in human affairs, one who is at the centre of a great cult, and one who is worshipped in a particular way by the mortals here portrayed. (p. 127)

Ion's quest is, in fact, an effort to improve his condition. But it is also a spiritual pursuit insomuch as he seems to live a double life. He so intensely professes to be a sanctimonious servant of the god that he has been successful not only in deceiving himself but also in deceiving most of his modern readers. It remains, however, that, despite his young age, lon does not always mean what he says. His spiritual journey is but an opportunistic effort to get ahead. He has no plan or moral principle other than convincing himself that he has such things. The play purports to be the aetiology of the lonians' come into power. As such, it was successful in showing that their ancestor was a determined, ambitious young man who counted with the favor of the gods. The lonians became famous for their love of empire, philosophy, speechifying, and pleasure! These traits 
were later expressed by the Athenians themselves, of which Euripides was one. Ion's spirituality then can only be expected to reflect these values, and it does.

\author{
Milton L. Torres \\ Centro Universitário Adventista de São Paulo, Brazil \\ email: milton.torres@ucb.org.br \\ Recibido: 05 de febrero de 2015 \\ Aceptado: 22 de mayo de 2015
}

\title{
References
}

Appleton, R. B. (1927). Euripides the idealist. London: J. M. Dent \& Sons.

Barlow, S. A. (1971). The imagery of Euripides. London: Methuen

Bömer, F. (1961). Untersuchungen über die Religion der Sklaven in Griechenland und Rom, Dritter Teil: Die wichtigsten Kulte der grieschischen Welt, Abhandlungen der geistesund sozialwissenschaftlichen Klasse..

Burnett, Anne P. (1962). Human resistance and divine persuasion in Euripides' Ion. Classical Philology 57, 89-103.

Burnett, Anne P. (1970). Ion by Euripides. Englewood Cliffs, NJ: Prentice Hall.

Burnett, Anne P. (1971). Catastrophe survived: Euripides' plays of mixed reversal. Oxford: Clarendon. Derrett, J. D. M. (2012). Oracles, myth, and Luke's nativity story. Novum Testamentum 54, 258-268. Hall, Edith (1997). The sociology of Athenian tragedy. In Easterling, P. E. (Ed.). The Cambridge companion to Greek tragedy. Cambridge, MA: Cambridge University Press.

Hartigan, Karelisa V. (1991). Ambiguity and self-deception: The Apollo and Artemis plays of Euripides. Frankfurt: Peter Lang.

Huys, Marc (1995). The tale of the hero who was exposed at birth in Euripidean tragedy: A study of motifs. Leuven, Belgium: Leuven University Press.

Jordan, B. (1979). Servants of the gods: A study in the religion, history and literature of fifthcentury Athens. Hypomnemata 55, 23-28.

Kearns, Emily (2013). Pindar and Euripides on sex with Apollo. Classical Quarterly 63 (1), 57-67.

Meagher, Robert E. (1989). Mortal wisdom: The wisdom of Euripides. New York: St. Martin's.

Murray, Gilbert (1912). Four stages of Greek religion: Studies based on a course of lectures delivered in April 1912 at Columbia University. London: Columbia University Press.

Norwood, Gilbert (1942). Euripides, lon. American Journal of Philology 63 (1), 109-113.

Owen, A. S. (1939). Euripides, Ion: Text with introduction and commentary. Oxford: Clarendon.

Von Wilamowitz-Moellendorff, Ulrich (1926). Euripides: Ion. Berlin: Weidmann.

Verrall, A. W. (1967 [1898]). Euripides the rationalist: A study in the history of art and religion. New York: Russell \& Russell.

Whitman, Cedric H. (1974). Euripides and the full circle of myth. Cambridge, MA: Harvard University Press.

Yunis, Harvey (1988). A new creed: fundamental religious beliefs in the Athenian polis and Euripidean drama. Hypomnemata 91, 7-192. 